JAKOB MAZIARZ (Kraków)

\title{
Czy historia prawa jest nauką historyczną czy prawną?
}

W propedeutycznych opracowaniach dotyczących prawoznawstwa dość powszechnie wskazuje się, iż nauki prawne dzielą się trojako: na filozofię prawa, dogmatykę oraz historię prawa ${ }^{1}$. Niezależnie od tego, czy uznamy słuszność tej koncepcji, czy też podążymy za inną - choćby zaprezentowaną przez Leona Petrażyckiego, wydaje się nie ulegać wątpliwości, że zawsze w tym podziale swoje miejsce mieć będzie historia prawa ${ }^{2}$. Nauki historycznoprawne, w przeciwieństwie do dogmatyki, mają dość krótką historię. Zakorzenione są właściwie w dziewiętnastowiecznej myśli prawniczej i - jak się przyjmuje dość powszechnie - ich wyodrębnienie jest bardzo istotną konsekwencją wpływów niemieckiej szkoły historycznej. Współcześnie podział nauk prawnych widoczny jest zwłaszcza w uniwersyteckiej dydaktyce prawniczej; brak jest właściwie innych jej przedstawicieli jak pracownicy wydziałów prawa.

Wydaje się, że w literaturze teoretycznoprawnej nie ma sporu co do tego, czy historia prawa jest w ogóle nauką prawną. Historia prawa nie jest także postrzegana jako odrębna dyscyplina historyczna przez środowisko historyków „bezprzymiotnikowych”" Dlatego też może dziwić, że wśród najbardziej zainteresowanych - środowiska historycznoprawnego bardzo popularny jest pogląd, jakoby historia prawa była dyscypliną historyczną, powiązaną $\mathrm{z}$ prawem jedynie $\mathrm{w}$ ten sposób, że pełni w stosunku do niego funkcje „służebne, choć nie usługowe"4.

1 Por. np. L. Morawski, Wstęp do prawoznawstwa, Toruń 2008, s. 33; K. Opałek, Problemy metodologiczne nauki prawa, Warszawa 1962, s. 95-96.

2 Por. L. Petrażycki, Wstęp do nauki prawa i moralności, Warszawa 1959, s. 11; K. Opałek, Z problematyki podziału nauk prawnych, „Zeszyty Naukowe Uniwersytetu Jagiellońskiego - Prace Prawnicze" 1960, s. 33.

3 J. Topolski, Metodologia historii, Warszawa 1968.

${ }^{4}$ Por. S. Grodziski, Uwagi o stużebnej, choć nie ustugowej roli nauki historii państwa i prawa, „Czasopismo Prawno-Historyczne” 2002, t. LIV, z. 2, s. 15-20 oraz pozycje powołanej niżej. 
Jak się wydaje, pogląd ten nie wytrzymuje jednak krytyki. Przedmiotem nauk prawnych jest prawo, nad którym badania można jednak prowadzić na wielu poziomach ${ }^{5}$ i z różnych perspektyw. Koronnym argumentem przemawiającym za uznaniem historii prawa za dyscyplinę historyczną jest przekonanie, któremu ulega profesor Stanisław Grodziski, iż przedmiotem badania jest prawo epok minionych, w stosunku do którego stosuje się metody historyczne ${ }^{6}$. Profesor Bogusław Leśnodorski podnosił, że dla historyków i historyków prawa wspólna jest metodologia oraz marksistowska teoria rozwoju społecznego ${ }^{7}$. W związku z upadkiem drugiego członu tej koncepcji pozostaje odnieść się tylko do metod stosowanych w historii prawa. Trudno się z zaprezentowanym rozumowaniem zgodzić. Historia nie wypracowała przecież żadnych metod służących wykładni i stosowaniu prawa, gdyż jest to co jest absolutnym notorium - domeną nauk prawnych. Jeżeli pragnęlibyśmy stosować metodologię ściśle historyczną w naukach historyczno-prawnych, w zasadzie prawo nieobowiązujące musielibyśmy sprowadzić do kwestii res factii. Przedmiotem badań wszystkich nauk prawnych jest jednak co do zasady prawo $^{8}$. Natomiast przedmiotem zainteresowania historii prawa jest prawo wszystkich epok, z wyjątkiem czasów najnowszych. W istocie podzielenie poglądu, iż historia prawa jest nauką historyczną, oznaczałoby, że należy przyjąć także, iż prawem jest tylko zespół norm obecnie obowiązujących. Istotnie pogląd taki istnieje - właściwie zasadza się na nim tzw. kompleks Kirchmanna. Podzielić należałoby jednak pogląd, że istotą prac prawdziwie naukowych w naukach prawnych jest to, że nie odchodzą one w niepamięć po zmianie stanu prawnego?

W pełni na uznanie zasługuje także pogląd Juliusza Bardacha, zgodnie z którym: „Zakres problemów, które dyscypliny historyczno-prawne mogą rozpatrywać, pokrywa się $\mathrm{z}$ zagadnieniami całego prawoznawstwa, tyle że rozpatruje się je z właściwym tym dyscyplinom «wyznacznikom czasowym»" ${ }^{10}$. Innymi słowy historia prawa to dogmatyka, której przedmiotem

${ }^{5} \mathrm{Na}$ uwagę zasługuje pogląd S. Ehrlicha, który wskazywał, iż badania nad prawem można prowadzić na trzech poziomach: antecedencji, analizy prawnej oraz analizy skutków funkcjonowania. Por. S. Ehrlich, Wstęp do nauki o państwie i prawie, Warszawa 1970, s. 143.

${ }^{6}$ S. Grodziski, Uwagi o historii prawa, jej miejscu wśród nauk historycznych i nazwie, „Historyka" 1972, t. III, 89-91.

${ }^{7}$ B. Leśnodorski, Historia wśród innych nauk historycznych, „Czasopismo Prawno-Historyczne" 1964 , t. XVI, z. 1, s. 307-310.

${ }^{8}$ K. Opałek, Z problematyki podziału ..., s. 33.

9 A. Mączyński, Uwagi o stanie nauki polskiego prawa cywilnego, „Państwo i Prawo” 2011, nr 6, s. 14.

10 J. Bardach, Themis a Klio, czyli o potrzebie podejścia historycznego w prawoznawstwie, [w:] Zagadnienia metodologiczne prawoznawstwa, [w:] (red.) J. Wróblewski, Materiały z sesji naukowej, Łódź 27-28 marca 1980 r., Warszawa 1982, s. 21-24. 
zainteresowania jest prawo już nieobowiązujące ${ }^{11}$. Prawo jest przy tym - co jest kolejnym notorium - bytem niesłychanie konserwatywnym, a jego siatka pojęciowa dezaktualizuje się bardzo powoli, nawet pomimo tego, że tempo zmian legislacyjnych przybrało niespotykane nigdy wcześniej rozmiary. $\mathrm{W}$ istocie jednak zmiany te uświadamiają nam tylko, że nullum est iam dictum, quod non sit dictum prius.

Trudno mi nie zgodzić się z opinią, iż naukowa analiza prawa, w tym formułowanie postulatów de lege lata i de lege ferenda, wymaga postawy zdecydowanie szerszej niż tylko skupienie się na analizie tekstu współczesnych przepisów. Nie powinno zatem dziwić, że przez długi czas historia traktowana była - w pewnym zakresie - jako nauka pomocnicza prawa ${ }^{12}$. Pozwala ona bowiem zbadać - i uwzględnić w procesie stosowania - pochodzenie i ewolucję norm prawnych. Intensywność działań ustawodawcy, nasilająca się z każdym rokiem, sprawiła jednak, iż większość współczesnych przepisów liczy sobie ledwie kilka, bądź też najwyżej kilkanaście lat ${ }^{13}$. Tymczasem jeszcze w połowie XX wieku powszechnie obowiązującymi, a przy tym o charakterze najbardziej podstawowym były normy pochodzące z początków wieku XIX (bądź też nawet lat wcześniejszych). Wydawać by się mogło zatem, że musi także maleć konieczność odwoływania się do wiedzy historycznej w procesie wykładni prawa. Tymczasem jednak o ile poszczególne przepisy ulegają zmianie, to - w znakomitej większości przypadków - instytucje prawne pozostają wciąż te same. Nie może zatem także dziwić, że Sąd Najwyższy, wyrokując na podstawie kodeksu cywilnego, odwołuje się choćby do jurysprudencji rzymskiej ${ }^{14}$ (romanistyka jest zresztą tą dyscypliną nauk historycznoprawnych, co do której nikt zdaje się nie mieć wątpliwości, iż nie jest ona nauką historyczną ${ }^{15}$ ), a większość prac dogmatycznych poprzedzonych jest historycznoprawnym wstępem ${ }^{16}$.

Usiłując rozważać charakter nauk historyczno-prawnych, nie należy zapominać o ich genezie. Początkowo rola historii prawa polskiego była najzu-

${ }^{11}$ Nie jest natomiast celem niniejszej pracy przytaczanie argumentów za sensownością prowadzenia takich badań.

12 S. Salmonowicz, Oratio pro domo sua, czyli kilka uwag o nauce historii prawa w Polsce, „Miscellanea Historico-Iuridica” 2011, t. X, s. 23.

${ }^{13}$ Przepisy prawa wekslowego oraz prawa czekowego są w tym zakresie właściwie jedynym chwalebnym wyjątkiem.

14 Por. np. uchwałę Sądu Najwyższego z dnia 18 lipca 2012 r., sygn. III CZP 41/12, Biuletyn SN 2012, nr 7 poz. 9 oraz postanowienie Sądu Najwyższego z dnia 20 kwietnia 2011 r., sygn. I CZ 21/11, OSNC-ZD 2012, nr 2 poz. 32.

${ }^{15}$ Metoda nauczania prawa rzymskiego nie różni się właściwie od metod stosowanych w naukach dogmatycznych. Nie sposób jednak stosować jej w pozostałych naukach historyczno-prawnych, ze względu na ich objętość. Byłoby najzupełniej zbędnym przyswajać sobie znajomość przepisów choćby najważniejszych kodyfikacji, w sytuacji kiedy w każdej chwili można sięgnąć do ich treści.

${ }^{16}$ Inną sprawą oczywiście jest jakość tych wstępów i cel ich zamieszczenia. 
pełniej praktyczna; historia prawa staropolskiego traktowana była wręcz jako nauka dogmatyczna. Zaczęto ją bowiem wykładać na polskich uniwersytetach (zarówno w Krakowie, jak i we Lwowie) w pierwszej połowie XIX w., z przyczyn typowo pragmatycznych - ciągle jeszcze prawo staropolskie znajdowało swoje zastosowanie w orzecznictwie sądowym (głównie bądź to na skutek niederogowania jego norm, bądź to na skutek przepisów intertemporalnych). Początkowo historia prawa polskiego w Uniwersytecie Jagiellońskim nauczana była łącznie z procedurą cywilną, a później - z prawem wekslowym i handlowym ${ }^{17}$. Dopiero z czasem, oprócz wątków typowo praktycznych, w naukach historycznoprawnych pojawiły się kwestie związane z historią państwowości polskiej, które z czasem wzięły przewagę. Już w II połowie XIX w. Oswald Balzer z satysfakcją pisał: ,przestaliśmy spoglądać na nią [historię prawa polskiego - przyp. autor] wyłącznie tylko ze stanowiska praktycznego; uprawiamy ją jako umiejętność"18.

Powody, dla których zaistniała historia prawa, nie ustały i nigdy nie ustaną. Absurdem byłaby także oczywiście próba udowadniania, że historia prawa ma istotny wpływ na codzienną praktykę prawniczą. Nie da się jednak również nie zauważyć, że w całkiem współczesnym orzecznictwie sądowym zdarzają się także historycznoprawne hard cases. Nie sposób nawet wskazać wszystkich powodów, dla których - pomimo licznych zabiegów ustawodawcy mających na celu likwidację stosunków prawnych mogących odwoływać się do prawa już nieobowiązującego - nadal istnieje taka potrzeba. Jedną z nich są z pewnością przepisy intertemporalne prawa prywatnego, które każą odwoływać się do zaborczego (czy nawet jeszcze wcześniejszego) prawa spadkowego $^{19}$, rzeczowego ${ }^{20}$, rzadziej prawa małżeńskiego ${ }^{21}$ czy zobowiązań ${ }^{22}$. Przykłady takie można mnożyć. Stosunkowo dobrze znane jest najnowsze orzecznictwo Trybunału Konstytucyjnego ${ }^{23}$ i Sądu Najwyższego ${ }^{24}$ oparte o ustawo-

${ }^{17}$ S. Grodziski, Historia ustroju społeczno-politycznego Galicji 1772-1848, Wrocław 1971, s. 21; idem, Cenny księgozbiór, „Alma Mater” 2005, nr 73, s. 42.

${ }_{18}$ O. Balzer, O obecnym stanie nauki prywatnego prawa polskiego i jej potrzebach, Lwów 1887, s. 1.

19 Por. np. wyrok Sądu Najwyższego z dnia 21 listopada 1997 r., sygn. I CKN 282/97 (LEX nr 1227407), wydany na gruncie przepisów ABGB.

${ }^{20}$ Por. np. wyrok Sądu Najwyższego z dnia 20 września 2012 r., sygn. IV CSK 46/12 (LEX nr 1227855), wydany na gruncie przepisów Kodeksu Napoleona.

${ }^{21}$ Por. np. wyrok Sądu Apelacyjnego w Krakowie z dnia 19 września 1995 r., sygn. I ACr 440/95 (niepubl.) wydany na gruncie przepisów ABGB.

22 Por. np. wyrok Sądu Apelacyjnego w Gdańsku z dnia 31 października 2001 r., sygn. I ACa 978/01 (OSA $2003 \mathrm{nr} 2$ poz. 5) wydany na gruncie przepisów BGB.

${ }^{23}$ Postanowienie Trybunału Konstytucyjnego z dnia 7 maja 2008 r., sygn. akt SK 14/06 (ZUTK $2008 \mathrm{nr} 4 \mathrm{~A}$ poz. 66) oraz zdanie odrębne sędziego TK B. Zdziennickiego do postanowienia Trybunału Konstytucyjnego z dnia 7 maja 2008 r., sygn. akt SK 14/06 (ZUTK 2008 nr 4A poz. 66).

${ }^{24}$ Wyrok Sądu Najwyższego z dnia 22 grudnia 2004 r., sygn. IV CK 622/03 (OSNC z 2005 r., nr 12 poz. 214) oraz uchwała Sądu Najwyższego w składzie 7 sędziów z dnia 18 kwietnia 2007 r., sygn. III CZP 139/06 (OSNC z 2007 r., nr 11 poz. 159). 
dawstwo carskie z czasów uwłaszczenia, mniej natomiast orzecznictwo sądów powszechnych, w których sięga się po prawo wieków średnich ${ }^{25}$. Nietrudno zgadnąć zatem, iż kwestii tych próżno byłoby współcześnie poszukiwać w dogmatyce prawniczej. W naukach historycznoprawnych - wprost przeciwnie.

Ujmowanie historii prawa jako dyscypliny historycznej jest zatem postępowaniem ahistorycznym, abstrahującym od pierwotnego i faktycznego celu istnienia tej dyscypliny. Niemniej jednak na postrzeganie historii prawa jako nauki historycznej z całą pewnością wpływ miała działalność wielu wybitnych XIX- i XX-wiecznych prawników polskich, którzy zajmowali się także historią - m.in. Władysława Konopczyńskiego, Michała Bobrzyńskiego, Stanisława Kutrzeby i wspomnianego już Oswalda Balzera. Oni też doprowadzili do przesunięcia punktu ciężkości historii prawa na historię ustroju staropolskiego, stojąc w wyraźniej opozycji do ówczesnych warunków politycznych. Próżno byłoby natomiast szukać przykładów zjawisk odwrotnych. Chociaż zatem w literaturze podkreśla się, że historyk prawa powinien dysponować kwantum wiedzy i umiejętności, których z zasady nie nabywa się na studiach prawniczych (czego typowym przykładem może być np. umiejętność korzystania $\mathrm{z}$ archiwalió $\mathrm{w}^{26}$ ), to przecież mają one charakter jedynie uboczny i służebny względem przedmiotu zainteresowania historii prawa ${ }^{27}$.

Problematyka polityczno-ustrojowa była i jest poruszana w jednakowym stopniu przez historię prawa, jak i historię „bezprzymiotnikową”. Naruszenie równowagi między historią ustroju (a więc w pewnym uproszczeniu - historią prawa, które współcześnie określamy jako konstytucyjne), a historią prawa sądowego było zagadnieniem zauważanym już przed wieloma laty. O. Balzer w przedostatnim dziesięcioleciu XIX w. pisał: ,„poświęciliśmy zanadto mało uwagi prawu prywatnemu i karnemu, pojętym w znaczeniu materialnem, jak i formalnem"28. Badaczy XIX-wiecznych można jednak usprawiedliwić. Działali oni bowiem w imię troski o ocalenie wiedzy o dorobku państwowości staropolskiej, wbrew zaborcom, niechętnym tego typu działalności naukowej. Ten sam zarzut stawiał jednak blisko wiek później B. Leśnodorski, który

25 Por. wyrok Sądu Rejonowego w Wieliczce z 12 czerwca 2006 r., sygn. I C 147/03 (niepubl.), wyrok Sądu Okręgowego w Krakowie z 6 marca 2007 r., sygn. II Ca 1891/06 (niepubl.), wyrok Sądu Rejonowego w Wieliczce z 25 stycznia 2008 r., sygn. I C 240/07 (niepubl.), wyrok Sądu Okręgowego w Krakowie z 26 listopada 2008 r., sygn. II Ca 1306/08 (niepubl.), wyrok Sądu Rejonowego w Wieliczce z 9 kwietnia 2010 r., sygn. I C 26/09 oraz wyrok Sądu Okręgowego w Krakowie z 12 października 2010 r., sygn. II Ca 1080/10 (niepubl.). Por. też: A. Górska, M. Paluch, Niezwykly spór Kościoła z nadleśnictwem na podstawie dokumentu z XIV w., „Gazeta Krakowska”, 3 września 2012 r. oraz J. Maziarz, Biegły sq̨dowy z zakresu historii prawa, Kraków 2014.

${ }^{26}$ S. Salmonowicz, op. cit., s. 33.

27 Tak samo jak znajomość języków obcych jest umiejętnością konieczną zwłaszcza dla osób zajmujących się tematyką prawnoporównawczą.

${ }^{28}$ O. Balzer, Studia nad prawem polskim, Poznań 1889, s. 20. 
choć kwalifikował historię prawa jako naukę historyczną, to napominał, nieco przeciw sobie, iż historyk prawa ,nie powinien tracić z pola widzenia wątków ściśle prawniczych, nie ograniczając się do ogólnych zagadnień państwa i społeczeństwa" 29 .

W opracowaniach o charakterze stricte historycznym można spotkać wątki prawne. Poza zagadnieniami ustrojowymi dotyczy to także prawa karnego - głównie jednak wieków średnich. W zasadzie próżno byłoby poszukiwać informacji dotyczących historii prawa prywatnego. Trudno zresztą dziwić się takiemu stanowi rzeczy. Historyk jest w taki sam sposób predysponowany do mówienia o historii prawa, jak przeciętnie wykształcony człowiek do dywagowania o prawie współczesnym. O ile jakąś wiedzę dotyczącą funkcjonowania państwa posiada, to zdecydowanie gorzej jest z prawem sądowym - tak prywatnym, jak i karnym, materialnym i procesowym.

Niesłychanie jednak trudno stwierdzić, gdzie kończy się historia prawa, a zaczyna dogmatyka. Najprawdopodobniej granicy takiej wcale nie ma. Działania ustawodawcy spowodowały, że prace o charakterze dogmatycznym pochodzące nawet sprzed ledwie kilku lat nie przystają już do obowiązującego stanu prawnego. Nie oznacza to jednak, że starsze opracowania dogmatyków utraciły swoją doniosłość i praktyczne znaczenie. Orzecznictwo sądowe i poglądy doktryny często zachowują swoje walory przez dziesiątki lat ${ }^{30}$, za granicą - zapewne nawet dłużej. Znakomitym tego przykładem może być art. 300 k.k., którego interpretacja nadal w znakomitej części opiera się na orzecznictwie Sądu Najwyższego z lat 1932-39³1. Wyraźnie widać to także na gruncie prawa zwalczania nieuczciwej konkurencji czy prawa wekslowego i czekowego ${ }^{32}$.

Znacznej części opracowań dogmatycznych opartych na nieobowiązującym już stanie prawnym (dotyczących wszystkich dziedzin prawa) nie sposób odmówić wartości praktycznej i uznawać je za dzieła wyłącznie (albo choćby w przeważającej mierze) historyczne. Miarą wartości każdej pracy prawniczej wydaje się właśnie fakt, iż nie poddaje się ona kompleksowi Kirchmanna ${ }^{33}$. W przeciwieństwie jednak do nauk dogmatycznych historia prawa nie jest obciążona tym problemem. Wszelka działalność ustawodawcy powiększa tylko

${ }^{29}$ B. Leśnodorski, op. cit., s. 306.

${ }^{30}$ Skłonny jestem zaryzykować twierdzenie, że pewna część nawet starszego orzecznictwa nie zdezaktualizowała się, niemniej kategoryczne wnioski winny być poparte dokładniejszymi badaniami niż poczynione przeze mnie do tej pory.

${ }^{31}$ Por. J. Majewski, Komentarz do art. 300 k.k., [w:] (red.) A. Zoll, Kodeks karny. Komentarz, t. III, Warszawa 2006.

${ }_{32} \mathrm{~W}$ tym przypadku oczywiście niebagatelne znacznie odgrywa fakt, iż stan prawny nie uległ zmianie od osiemdziesięciu lat.

33 Por. np. F. Zoll, Wstęp, [w:] (red.) J. Pisuliński, F. Zoll, Rozprawy z prawa cywilnego, własności intelektualnej i prawa prywatnego międzynarodowego. Księga pamiątkowa dedykowana Profesorowi Bogusławowi Gawlikowi, Warszawa 2012. 
jej pole działania. Co więcej - tendencja ta może mieć tylko jeden kierunek. Im bardziej aktywny jest ustawodawca, tym większy jest zakres przedmiotowy historii prawa.

Może dziwić, że wśród historyków prawa dominuje tendencja do określenia historii prawa jako nauki historycznej. Marek Wąsowicz na pytanie „czy historyk prawa jest «bardziej» historykiem czy prawnikiem?” odpowiada: „historyk prawa, bez względu na to, jaką problematyką się zajmuje, jest jednak przede wszystkim historykiem. (...) W dociekaniach prawnika góruje bowiem postawa postulująca: prawnik zastanawia się nad tym, jakie prawo powinno być, jak powinno się je stosować, jak go przestrzegać. W rozważaniach historyka dominuje natomiast postawa wyjaśniająca: próbuje on opisywać i thumaczyć przeszłość. Historyk prawa bada przeszłe prawo, dlatego też (...) w jego rozważaniach musi dominować postawa tłumacząca, właściwa historykowi”34. $\mathrm{Z}$ tezą taką trudno się zgodzić, albowiem argumenty prezentowane przez autora są semantycznie puste. Równie dobrze można byłoby bowiem powiedzieć, że prawnik ,próbuje opisywać i tłumaczyć” prawo współczesne, a historyk prawa poprzez analizę przeszłości ,zastanawia się nad tym, jakie prawo powinno być, jak powinno się je stosować, jak go przestrzegać”. Zaprezentowany pogląd sugeruje, że z punktu widzenia jakości, stosowania i przestrzenia prawa jego historia jest w zasadzie nieistotna. Teoria, iż historia prawa powinna sprowadzać się wyłącznie (albo choćby - w przeważającym stopniu) do problematyki opisowej jednoznacznie wskazuje, że nie ma ona żadnego przełożenia na praktykę jego stanowienia i stosowania współcześnie. Być może pogląd taki reprezentuje pewna część dogmatyki i praktyki prawniczej, niemniej prezentowany przez historyka prawa może budzić kontrowersje.

$\mathrm{Z}$ punktu widzenia podejścia do przedmiotu badań nie ma żadnej różnicy między współczesnym cywilistą koncentrującym swoje zainteresowania na regulacjach kodeksu z 1964 r., a historykiem prawa, który skupia swoją aktywność na przepisach ABGB, BGB czy Kodeksu Napoleona. Metody mogące być przez nich stosowane są właściwie takie same, taki sam (choć nie ten sam) jest przedmiot ich badań. Także sięgając do odleglejszych epok zarówno przedmiot badań i metoda badawcza w gruncie rzeczy nie ulega zmianie. Jeżeli bowiem za prawo (zatem nie za przedmiot res factii) uznajemy nieobowiązujący już kodeks karny z 1969 r., to dlaczego nie miałaby nim być Constitutio Criminalis Carolina z 1532 r.? Ktokolwiek miałby okazję zapoznać się z jej treścią, zawsze będzie zdziwiony, jak niewiele zmieniło się przez setki lat - i to zarówno w zakresie formułowania przepisów, języka prawnego, jak i podstaw odpowiedzialności karnej. Zinterpretowanie przepisów Caroliny dla współczesnego prawnika nie powinno (czy czym określenia „nie powinno” używam w sensie postulatywnym, nie opisującym) być pro-

${ }^{34}$ M. Wąsowicz, O profesji historyka prawa, „Przegląd Humanistyczny” 1989, nr 3, s. 20-21. 
blemem przerastającym jego możliwości. Jak się wydaje - nie jest bowiem celem studiów prawniczych uczenie się na pamięć treści obowiązujących (w gruncie rzeczy - tylko przejściowo) przepisów, a umiejętność dokonania wykładni prawa niezależnie od jego walorów temporalnych. S. Grodziski, choć klasyfikuje jednoznacznie historię prawa jako naukę historyczną, to zaznacza wyraźnie, że ,nie ulega wątpliwości, że historycy prawa powinni posiadać wykształcenie prawnicze i praktykę" ${ }^{35}$, bowiem dokonując opisu i oceny zjawisk historycznych zawsze koniecznym musi być ich odniesienie do teraźniejszości i przyszłości.

Prawo dawne objaśnia się i systematyzuje, tak jak prawo współczesne. Często nawet zarzutem stawianym historykom prawa, zwłaszcza romanistom, jest to, iż w swoich działaniach przejawiają oni daleko idący ahistorycyzm, zajmując się bardziej treścią przepisów prawa, niż faktyczną praktyką ich stosowania $^{36}$. Nie popadając w sprzeczność, można orzec, że w naukach historycznoprawnych daleko idące znaczenie ma metoda formalno-dogmatyczna. Dużo trudniej byłoby natomiast poszukiwać metod charakterystycznych wyłącznie dla nauk historycznych. Nawet jednak przyjmując, iż pokaźną część historii prawa stanowią opracowania dotyczące praktycznego stosowania prawa, a nie tylko jego treści, to w niczym nie ujmuje to jednak ich prawniczemu charakterowi. Wszak kryminologia, socjologia prawa i znaczna część nauk dogmatycznych (w tym w zasadzie całość analizy orzecznictwa) opiera się na analizie prawa $w$ działaniu, nie zaś tylko prawa $w$ księgach.

Pewne zjawiska są przedmiotem badań wielu dyscyplin. Praktycznie każda pochwalić się może opracowaniami dotyczącymi zagadnień historycznych. Dotyczy to nie tylko nauk prawnych, czy nawet nie tylko nauk humanistycznych i społecznych, ale i takich, które trudno byłoby wiązać, nawet pośrednio, z naukami historycznymi. Zinstytucjonalizowane formy, znajdujące swoje odbicie np. w istnieniu jednostek uniwersyteckich, posiada nie tylko historia filozofii czy ekonomii, ale także historia matematyki, historia medycyny czy historia techniki ${ }^{37}$. Pomimo tego jednak naiwnością byłoby twierdzić, że historyk matematyki jest bardziej historykiem niż matematykiem ${ }^{38}$.

Juliusz Bardach wyróżniał dwie płaszczyzny, na których dochodziło do zetknięcia się historii i prawa: pierwszym były dyscypliny historycznoprawne, które zaliczał zarówno do nauk historycznych, jak i do prawnych, a drugim - podejście historyczne w prawoznawstwie, rozumiane jako spo-

35 S. Grodziski, Uwagi o historii prawa ..., s. 93.

${ }^{36}$ K. Opałek, Z problematyki podziału ...., s. 31.

37 Zakłady Historii Matematyki oraz Historii Medycyny są jednostkami Uniwersytetu Jagiellońskiego, Historii Techniki - Akademii Górniczo-Hutniczej.

${ }^{38}$ Ktokolwiek nie jest przekonany co do takiego poglądu, powinien zapoznać się z dorobkiem historyków matematyki i odpowiedzieć sobie na pytanie, czy do jego zrozumienia bardziej przydatna jest wiedza matematyczna czy historyczna? 
sób badania prawa $\mathrm{z}$ wykorzystaniem aparatu naukowego, jakim dysponują dyscypliny historyczne ${ }^{39}$. Nie wchodząc w dywagacje dotyczące słuszności takiego podziału, zauważyć należy, że dokonanie go każe przyjąć, iż wątki historycznoprawne można poruszać dwojako: można mówić o prawie współczesnym z pespektywy jego historycznego rozwoju (analizować współczesne rozwiązanie prawne na gruncie jest ewolucji) albo też można mówić o prawie dawnym, w sposób, w jaki mówi się o prawie obecnie obowiązującym (a więc - w znakomitej części przypadków: stosując metodę dogmatyczną). $\mathrm{W}$ obydwóch tych przypadkach bardzo istotny jest właśnie element prawa, jako przedmiotu badań.

Jakkolwiek prace Juliusza Bardacha dotyczące roli historii prawa nie zawsze wytrzymują próbę $\mathrm{czasu}^{40}$, to na pełną aprobatę zasługuje teza, że badania historycznoprawne w ostatecznym rozrachunku mają na celu poszukiwanie w przeszłości źródeł i korzeni teraźniejszości, a także elementów pozwalających przewidzieć (i jak się wydaje - także próbować ukształtować) przyszłość. Historia prawa jednocześnie jest więc retrospektywna i perspektywiczna; zdecydowanie nawet bardziej niż historia „ogólna”.

$\mathrm{Z}$ całą pewnością z punktu widzenia dogmatyki prawniczej zdecydowanie najbardziej popularne jest odnoszenie się do stanu prawnego bezpośrednio poprzedzającego stan obowiązujący. Byłoby to z pewnością uzasadnionym argumentem przemawiającym za przewagą elementu czysto historycznego w naukach historycznoprawnych, które nie mają wpływu na współczesną dogmatykę. Powszechne zauważalne jest jednak, że we współczesnej historii prawa dominuje bardzo wyraźnie tendencja do skupiania się na prawie jeszcze stosunkowo niedawno obowiązującym, a więc XIX- i XX-wiecznym ${ }^{41}$.

Historia prawa nie jest zatem nauką historyczną, a nieporozumienia związane z jej kwalifikowaniem wynikają z tego, że historycy prawa - zarówno ci XIX-wieczni, przywołani wyżej, jak i zupełnie współcześni - często zajmują się także uprawianiem historii. Zdecydowanie rzadziej znajdują jednak czas na praktykę i dogmatykę prawniczą, a przez to także na próby poszukiwania współczesnego zastosowania doświadczeń zdobytych na gruncie historycznej analizy prawa. Nie bez przyczyny wśród bogatego dorobku przywołanych wyżej autorów, którzy historię prawa kwalifikują jako naukę historyczną, znaczną część (czasem nawet dominującą) zajmują publikacje (niekiedy znakomite), których nie sposób zakwalifikować jako historycznoprawnych ${ }^{42}$.

39 J. Bardach, Themis a Klio..., s. 25.

40 J. Bardach, Miejsce historii państwa i prawa w systemie nauk prawnych i jej rola $w$ ksztatceniu prawniczym, s. 765-766.

${ }^{41}$ A. Zakrzewski, Czemu ma obecnie służyć historia prawa, co jej grozi?, „Miscellanea Historico-Iuridica" 2011, t. X, s. 43.

${ }^{42}$ Por. np. S. Grodziski, Franciszek Józef I, Wrocław 2006; idem, Habsburgowie: dzieje dynastii, Kraków 2013; idem, Rzeczpospolita Krakowska, jej lata i ludzie, Kraków 2012; M. Wąsowicz, Między tronem, giełda i barykada: Francja 1830-1848, Warszawa 1994. 
Z drugiej strony czasem zdarza się także, że to historycy poruszają zagadnienia (historyczno)prawne (choć jak wskazano wyżej - dotyczy to w gruncie rzeczy tylko historii prawa państwowego i to dosyć odległego) ${ }^{43}$. Dlatego też przestaje dziwić, że choć teoretycy prawa nie kwestionują, iż historia prawa jest nauką prawną, robią to sami historycy prawa. Uprawiają oni historię, będąc przy tym historykami prawa; $\mathrm{z}$ istnienia tych przesłanek wyciągają jednak błędny wniosek, nieuprawnienie na swoje potrzeby generalizując.

Historia prawa z całą pewnością nie jest nauką praktyczną, co jednak nie odbiera jej przymiotu nauki prawnej. Miał rację Witold Zakrzewski, pisząc już prawie 40 lat temu, iż o coraz wątlejszym przekonaniu w organiczny rozwój instytucji prawnych, tak charakterystycznym dla historycznej szkoły prawa, świadczą wątlejsze wstępy historyczne w publikacjach dogmatycznych ${ }^{44}$. Być może jednak powodów takiego stanu rzeczy należy poszukiwać w samym środowisku historycznoprawnym, które zbyt hermetycznie podchodzi do zagadnień będących przedmiotem swoich badań i zbyt rzadko uwypukla bardziej współczesne ich aspekty. Klasyfikowanie z tego powodu historii prawa jako nauki historycznej jest $\mathrm{z}$ tych powodów nieuzasadnionym wnioskowaniem o rzeczywistości, opartym nie o obiektywne przesłanki, a o osobiste preferencje części środowiska.

\section{IS HISTORY OF LAW A SCIENCE OF HISTORY OR A SCIENCE OF LAW?}

\section{Summary}

The article examines the grounds for the classification of the history of law as a science of history, or a science of law. It is a polemics with the long-standing view of representatives of the legal history science who would like to reduce the role of the history of law to that of an ancillary subject of the science of history. Arguments contained in the article support a thesis that the history of law may only be perceived as part of jurisprudence whereas the argument that it may form one of the sciences of history has been rejected on the basis of historic, comparative and theoretical argumentation.

${ }^{43}$ Por. np. E. Opaliński, Król a prawo stanów do oporu, Kraków 2010; idem, Sejm srebrnego wieku 1587-1652: między glosowaniem większościowym a liberum veto, Warszawa 2011.

44 W. Zakrzewski, Nauki historycznoprawne a prawo pozytywne, „Czasopismo Prawno-Historyczne" 1964, z. 1, s. 292-295. 


\section{L'HISTOIRE DU DROIT EST-ELLE UNE SCIENCE HISTORIQUE OU JURIDIQUE?}

\section{Résumé}

L'article porte sur la problématique de qualifier l'histoire du droit, est-elle plutôt une science juridique ou science historique? Le présent travail entretient ainsi une polémique avec les opinions existantes depuis des années des représentants des sciences historico-juridiques aux yeux desquels ces dernières sont des sciences auxiliaires de l'histoire. L'auteur présente des arguments selon lesquels l'histoire du droit peut être perçue uniquement en tant qu'une partie de la science du droit. Il rejette par contre la possibilité de la concevoir comme l'une des sciences historiques, faisant référence aux arguments historiques, comparatifs et théoriques. 